\title{
I Like the Way You Eat It: Lemur (Indri indri) Gut Mycobiome and Geophagy
}

\author{
Luigimaria Borruso $^{1}$ (D) - Alice Checcucci ${ }^{2}$. Valeria Torti ${ }^{3}$. Federico Correa ${ }^{2} \cdot$ Camillo Sandri $^{2,4} \cdot$ Daine Luise $^{2}$. \\ Luciano Cavani ${ }^{2}$. Monica Modesto ${ }^{2}$. Caterina Spiezio ${ }^{4}$ - Tanja Mimmo ${ }^{1}$ - Stefano Cesco ${ }^{1} \cdot$ Maura Di Vito $^{5}$. \\ Francesca Bugli ${ }^{5,6} \cdot$ Rose M. Randrianarison ${ }^{7,8} \cdot$ Marco Gamba $^{3}$ - Nianja J. Rarojoson ${ }^{9} \cdot$ Cesare Avesani Zaborra ${ }^{4}$. \\ Paola Mattarelli ${ }^{2} \cdot$ Paolo Trevisi $^{2} \cdot$ Cristina Giacoma $^{3}$
}

Received: 29 September 2020 / Accepted: 28 December 2020 / Published online: 20 January 2021

(C) The Author(s) 2021

\begin{abstract}
Here, we investigated the possible linkages among geophagy, soil characteristics, and gut mycobiome of indri (Indri indri), an endangered lemur species able to survive only in wild conditions. The soil eaten by indri resulted in enriched secondary oxidehydroxides and clays, together with a high concentration of specific essential micronutrients. This could partially explain the role of the soil in detoxification and as a nutrient supply. Besides, we found that soil subject to geophagy and indris' faeces shared about $8.9 \%$ of the fungal OTUs. Also, several genera (e.g. Fusarium, Aspergillus and Penicillium) commonly associated with soil and plant material were found in both geophagic soil and indri samples. On the contrary, some taxa with pathogenic potentials, such as Cryptococcus, were only found in indri samples. Further, many saprotrophs and plant-associated fungal taxa were detected in the indri faeces. These fungal species may be involved in the digestion processes of leaves and could have a beneficial role in their health. In conclusion, we found an intimate connection between gut mycobiome and soil, highlighting, once again, the potential consequent impacts on the wider habitat.
\end{abstract}

Keywords Mycobiome $\cdot$ Gut $\cdot$ Soil quality $\cdot$ Non-human primates $\cdot$ Conservation $\cdot$ Indri indri

\section{Introduction}

Geophagy, the intentional consumption of soil, is practiced by many different human cultures over different continents [1]. Cultural tradition, together with sensory trap, hunger or stress relief, are the main three non-adaptive explanations for human geophagy [1]. The well-documented occurrence of geophagic

Luigimaria Borruso

luigimaria.borruso@unibz.it

Paola Mattarelli

paola.mattarelli@unibo.it

1 Faculty of Science and Technology, Free University of Bolzano-Bozen, Piazza Università 5, 39100 Bolzano-Bozen, Italy

2 Department of Agricultural and Food Sciences, University of Bologna, Viale Fanin 44, 40127 Bologna, Italy

3 Department of Life Sciences and Systems Biology, University of Torino, Torino, Italy

4 Department of Animal Health Care and Management, Parco Natura Viva - Garda Zoological Park, Bussolengo, Verona, Italy behaviour in many vertebrates, including non-human Primates, encourages the formulation of two main adaptive hypotheses: (i) the supplementation function consisting of supplementing microelements that are lacking in the diet and (ii) the protective function of soil in $\mathrm{pH}$ regulation, against toxins and parasites [2]. In this respect, lemurs' radiation in more than 100 species, colonizing different habitats and

5 Dipartimento di Scienze Biotecnologiche di Base, Cliniche Intensivologiche e Perioperatorie, Università Cattolica del Sacro Cuore, Largo A. Gemelli 8, 00168 Rome, Italy

6 Dipartimento di Scienze di Laboratorio e Infettivologiche, Fondazione Policlinico Universitario A. Gemelli IRCCS, Largo A. Gemelli 8, 00168 Rome, Italy

7 Groupe d'Étude et de Recherche sur les Primates de Madagascar (GERP), Cité des Professeurs, Fort Duchesne, BP 779, 101 Antananarivo, Madagascar

8 Mention d'Anthropobiologie et de Développement Durable (MADD), Université de Antananarivo, Antananarivo, Madagascar

9 Laboratoire de Pédologie, FOFIFA à Tsimbazaza, BP.1690 Antananarivo, Madagascar 
performing soil eating in at least 40 species, make them a very promising model for untangling the causes and functional consequences of geophagy [3]. Indri (Indri indri), the biggest among living lemurs, has a well-documented feeding and geophagy behaviour. This lemurs species is classified as 'critically endangered' by the IUCN Red List of Threatened Species due to the destruction and fragmentation of its habitat [4]. Furthermore, indris have never been successfully bred in captivity [5]. This evidence suggests that some behavioural and environmental factors are not satisfied with the already tested captivity protocols.

The indris' diet is mainly folivorous (i.e. immature leaves), but it may include even bark, seeds, flowers and fruits [5] (Fig. $1 \mathrm{~b}$, c and d, Supplementary Video S1). In the folivorous diet, the interactions between host and gut microbiome are necessary for the processes involved in cellulase activities due to the absence of these enzymes in all vertebrates [6, 7]. Primates' gut harbour a plethora of microbes, including archaea, bacteria and fungi, which play a crucial role in the digestion process, health and behaviour [8-11]. Despite the limited studies on primate mycobiome, indications are now accumulated on the fungi's important role in host physiology $[12,13]$. However, there is evidence that the primates' gut lacks a stable core mycobiome, unlike the bacterial microbiome [14]. In this respect, to define if a fungal species inhabits the gut stably or transiently remains an open question. The high interindividual variability can be explained considering that diet, geography and environment are the primary drivers in shaping the mycobiome composition [10] and fungal species of environmental or food-associated origin could transiently colonise the gut influencing the mycobiome composition. In this regard, we aimed to investigate the linkages between geophagic soil and indris gut mycobiome, using samples collected in the Maromizaha forest (Madagascar) (Fig. 1a). Specifically, we evaluated (i) the possible role of the soil properties eaten by indris and (ii) the putative geophagic soil contribution to the fungal communities inhabiting the indris' gut.

\section{Material and Methods}

\section{Behavioural Observation, Faecal and Soil Sample Collection}

All the samples were obtained from indris (faecal material) and geophagic soils in Maromizaha forest (latitude $18^{\circ} 57^{\prime} \mathrm{S}$ and $19^{\circ} 00^{\prime} \mathrm{S}$, longitude $48^{\circ} 26^{\prime} \mathrm{E}$ and $48^{\circ} 31^{\prime} \mathrm{E}$, Madagascar) between December 4 and 6, 2018 (Fig. 1a). Indris has been the subject of ongoing etho-ecological studies since 2009 [15]. Records are kept as photographs or videos.

Faecal samples were collected from 9 individuals (Table 1) following the groups' activity patterns in their natural habitat. Every single individual was recognised by natural trough marks [16]. We collected faecal samples immediately after

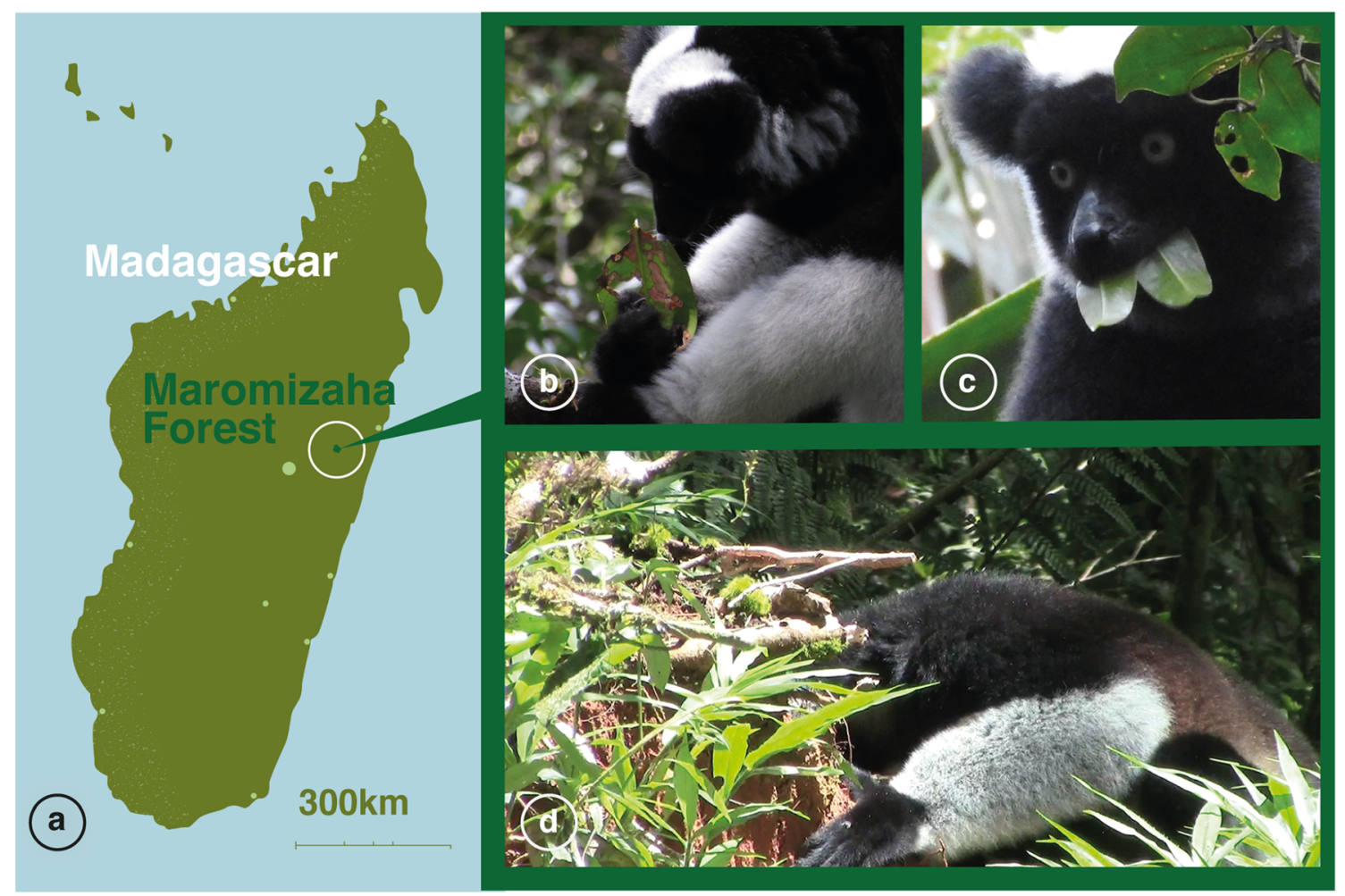

Fig. 1 a Localisation of the study site, the Maromizaha Forest, in north-eastern Madagascar; (b) indri eating a mature, speckled leaf; (c) indri eating young leaves; (d) indri eating soil from a fallen tree site 
Table 1 Information of the indris and soils considered

\begin{tabular}{lllll}
\hline Name & Group & Age (years) & Sex & Geophagic behaviour \\
\hline Bemasoandro & $8 \mathrm{MZ}$ & $>6$ & Female & Yes \\
Emè & $8 \mathrm{MZ}$ & 1 & Male & Yes \\
Zafy & $8 \mathrm{MZ}$ & 6 & Male & Yes \\
Eva & $4 \mathrm{MZ}$ & $>6$ & Female & Yes \\
Koto & $4 \mathrm{MZ}$ & $>6$ & Male & Yes \\
Mahagaga & $3 \mathrm{MZ}$ & $>6$ & Male & Yes \\
Bevolo & $1 \mathrm{MZ}$ & $>6$ & Female & Yes \\
Cami & $1 \mathrm{MZ}$ & 1 & Female & Yes \\
Dary & $2 \mathrm{MZ}$ & 6 months & Unknown & Yes \\
\hline
\end{tabular}

defecation, when only one animal was present, to avoid individual misidentification during the sampling process [15]. Disposable sterile gloves were worn when collecting samples to prevent contamination. Specifically, about $5 \mathrm{~g}$ of faeces was collected into screw-capped tubes, with an integrated plastic shovel-like tool attached to the cap, containing $10 \mathrm{ml}$ of RNAlater (Thermofisher, Waltham, MA, USA). The stool amount was taken from the middle of each fresh piece of faeces to avoid soil contamination. Next, the small plastic shovel-like tool attached to the cap of screw-capped tubes was used to scoop faecal samples. Every container was sealed immediately after the collection to avoid cross-contamination among samples. Seven soil samples (Table 1) were collected from the seven geophagy sites. All samples have been preserved in a portable refrigerator and then stored at $-20^{\circ} \mathrm{C}$ in the laboratory until downstream analysis.

\section{Soil Characterisation}

Soil samples were air-dried, milled and sieved at $2 \mathrm{~mm}$ for soil analysis in agreement with SSSA methods [17]. Briefly, total carbon $\left(\mathrm{C}_{\mathrm{tot}}\right)$ and total nitrogen $\left(\mathrm{N}_{\mathrm{tot}}\right)$ were determined using an elemental analyser (Flash 2000, Thermo Scientific, Germany) coupled with an isotopic mass spectrometer (DELTA Advantage, Thermo Scientific, Germany). Pseudo total element concentration was determined after acid mineralisation with aqua regia and hydrogen peroxide in an Ethos TC microwave lab station (Milestone, Bergamo, Italy) by an inductively coupled plasma optical emission spectrometer (ICP-OES, Ametek Spectro, Arcos, Germany). Iron, aluminium, titanium and silica oxide concentrations were determined by ICP-OES (Ametek Spectro, Arcos, Germany) after extraction with sodium dithionite $\left(\mathrm{Na}_{2} \mathrm{~S}_{2} \mathrm{O}_{4}\right)$.

\section{DNA Extraction and NGS Sequencing}

Total DNA extraction from $200 \mathrm{mg}$ faecal and soil samples was carried out using the DNeasy PowerSoil Kit (QIAGEN, Hilden, Germany) with a modification to the protocol including a pre-treatment with lyticase. Briefly, the samples were initially treated with 200 U lyticase (Sigma-Aldrich Co., Gillingham, UK), homogenised and incubated for $30 \mathrm{~min}$ at room temperature [18]. Lastly, the DNA was eluted twice to improve yield. Extracted DNA was quantified using a QuBit 2.0 Fluorometer Assay (Life Technologies Corporation) and then adjusted at $1 \mathrm{ng} \mu \mathrm{L}^{-1}$.

Fungal ITS region was amplified using the primer pairs ITS3 (5'-TCGTCGGCAGCGTCAGATGTGTATAA GAGACAGGCATCGATGAAGAACGCAGC-3') and ITS4 (5'-GTCTCGTGGGCTCGGAGATGTGTATAAGAGAC AGTCCTCCGCTTATTGATATGC $3^{\prime}$ ) modified with the required Illumina sequencing adaptors [19]. PCR was conducted in a total reaction volume of $25 \mu$ using the Platinum ${ }^{\mathrm{TM}}$ Taq DNA Polymerase High Fidelity (Thermo Fisher Scientific, Italy), $1 \mu \mathrm{l}$ of each primer $(10 \mu \mathrm{M})$ and $2.5 \mu \mathrm{L}$ of DNA template. In all samples, $0.4 \mathrm{mg} / \mathrm{ml}$ BSA was added. The thermal cycling protocol consisted of $94{ }^{\circ} \mathrm{C}$ for $2 \mathrm{~min}$ followed by 30 cycles each of $30 \mathrm{~s}$ at $94{ }^{\circ} \mathrm{C}, 30 \mathrm{~s}$ at $53{ }^{\circ} \mathrm{C}$ and $30 \mathrm{~s}$ at $72{ }^{\circ} \mathrm{C}$ and final elongation at $72^{\circ} \mathrm{C}$ for $5 \mathrm{~min}$. The libraries were prepared by BMR-Genomics Ltd. (http://www. bmr-genomics.it/) and sequenced on the MiSeq platform (Illumina Inc., San Diego, Ca, USA).

\section{Bioinformatics Analysis and Statistical Analysis}

Raw data were quality checked via FastQC [20]. Sequences were pre-processed, quality filtered, trimmed, de-noised, merged, modelled and analysed via DADA2 within QIIME2 [21]. Chimeras were discarded using the 'consensus' method [22]. Finally, the sequences variants were clustered using VSEARCH with a cut-off of 97\% [23]. The taxonomy annotation was performed using a Naïve-Bayes classifier trained on the UNITE+INSD database against the representative sequences [24]. The taxonomic annotated OTU table was parsed against the FunGuild (v1.0) database to assign putative functional guilds to each sample [25]. All sequences have been submitted to the European Nucleotide Archive (EMBL-EBI) under the study accession number PRJEB39443 (sample accession number from ERS4827963 to ERS4827978). Cryptococcus sequences were aligned using CLUSTALW [26]. For phylogenetic reconstruction, the neighbour-joining algorithm and Kimura's two-parameter model were used with complete deletion of positions containing gaps or missing data and 1000 bootstrap replications [27]. Phylogenetic analyses were carried out in MEGAX version 10.2 [27].

Rarefaction curves and Venn diagram were created using 'ggplot' and 'vegan' packages within the ' $\mathrm{R}$ ' environment [28-30]. Linear discriminant analysis effect size (LEfSe) algorithm (considering an LDA score $\geq 2$ and $p$ value $<0.05$ ) was applied to discover the most abundant fungal genera (average $>0.3 \%$ ) and functional guilds associated with indri and 
soil samples [31]. All the analyses were performed on rarefied data to 1154 reads.

\section{Results and Discussion}

\section{Geophagy}

In all nine individuals considered in this study (Table 1), we observed soil eating behaviour and a quite stereotypical ingestion method (Fig. 1d; Supplemental Video S1). The focal group always moved to a precise location solely for soil consumption. In all soil feeding-bouts observed, an indri descended first to the ground, jumping from a tree or a liana near the geophagy site, and started to eat soil. During one soil feeding-bout, one member of the group began to eat. The other members approached the site and stayed on the nearest trees monitoring the surrounding environment $(<10 \mathrm{~min})$ till he/she left the site, and a new indri took his/her turn in eating soil, one after the other.

The individuals consumed the soil directly by eating the exposed horizons with the mouth or collecting a small amount of soil with the hand and successively introducing it into the mouth.

When the mother carried the babies (i.e. Eme and Cami) (Table 1) and the female entered the site, we observed geophagy also in the youngest animals (Supplemental Video S1). After all individuals had fed, the group scurried out of the geophagy site. Next, the group reached a new location for eating or resting. Geophagy sites observed were mostly in the proximity of fallen trees, landslides or soft mounds of earth, revealing the lower soil horizons. There were exposed soils at the bases of trees uprooted by wind or rainfall in the valley, at lower elevations, in the slopes. All the locations were relatively free of debris (grass, leaves, stones, etc.) (Supplementary Video S1).

\section{Geophagic Soil Composition}

Soil composition analysis revealed that the different sampling sites might be classified as Oxisols rich in secondary oxidehydroxides and highly weathered clays [32]. In particular, soil analysis revealed that the sandy loam was characterised by a quite acid $\mathrm{pH}$, relatively rich in organic carbon, total nitrogen, potassium and magnesium, but poor in phosphorous and calcium (Table 2). Soil components as secondary oxidehydroxides are characterised by a high specific surface area, being thus ideal candidates for the gut detoxification of indri. This type of soil could be involved in the plant toxin adsorption, such as tannins, terpenes and cyanogenic glycosides derived from the diet based on immature fruits and leaves [2, 33]. Further, the low $\mathrm{pH}$ is a common characteristic of geophagic soils [34]; a consequent higher metal availability
Table 2 Geophagic soil characteristics, average and standard error (es)

\begin{tabular}{|c|c|c|}
\hline Geophagic soil & & Average \pm es \\
\hline \multirow[t]{4}{*}{ Granulometry } & Clay & $14.7 \pm 1.4$ \\
\hline & Silt & $8.9 \pm 0.9$ \\
\hline & Sand & $76.4 \pm 1.2$ \\
\hline & $\mathrm{pH}(\mathrm{H} 2 \mathrm{O})$ & $4.2 \pm 0.1$ \\
\hline \multirow[t]{3}{*}{ Total carbon and nitrogen } & $\mathrm{N}(\%)$ & $0.23 \pm 0.02$ \\
\hline & $\mathrm{C}(\%)$ & $3.18 \pm 0.31$ \\
\hline & $\mathrm{C} / \mathrm{N}$ & $13.71 \pm 0.41$ \\
\hline \multirow[t]{20}{*}{ Pseudo total elements (mg/kg) } & $\mathrm{Al}$ & $77273 \pm 5638$ \\
\hline & $\mathrm{Ca}$ & $427 \pm 91$ \\
\hline & $\mathrm{Co}$ & $6.08 \pm 1.61$ \\
\hline & $\mathrm{Cr}$ & $46.67 \pm 9.64$ \\
\hline & $\mathrm{Cu}$ & $15.49 \pm 4.48$ \\
\hline & $\mathrm{Fe}$ & $39394 \pm 6102$ \\
\hline & $\mathrm{K}$ & $476 \pm 192$ \\
\hline & $\mathrm{Mg}$ & $263 \pm 108$ \\
\hline & $\mathrm{Mn}$ & $201 \pm 61$ \\
\hline & Mo & $2.57 \pm 0.58$ \\
\hline & $\mathrm{Na}$ & $104 \pm 14$ \\
\hline & $\mathrm{Ni}$ & $17.35 \pm 5.81$ \\
\hline & $\mathrm{P}$ & $287 \pm 51$ \\
\hline & $\mathrm{Pb}$ & $39.93 \pm 5.28$ \\
\hline & $\mathrm{S}$ & $279 \pm 16$ \\
\hline & $\mathrm{Si}$ & $279 \pm 98$ \\
\hline & $\mathrm{Sn}$ & $3.17 \pm 0.28$ \\
\hline & $\mathrm{Ti}$ & $2212 \pm 491$ \\
\hline & $\mathrm{V}$ & $67.42 \pm 24.54$ \\
\hline & $\mathrm{Zn}$ & $55.51 \pm 10.10$ \\
\hline \multirow[t]{3}{*}{ Dithionite-extractable metals (mg/kg) } & $\mathrm{Al}$ & $3580 \pm 463$ \\
\hline & $\mathrm{Fe}$ & $7988 \pm 852$ \\
\hline & $\mathrm{Ti}$ & $156 \pm 37$ \\
\hline
\end{tabular}

could be advantageous for their incorporation in the biological processes. In addition, soils were rich in manganese $(\mathrm{Mn})$ and iron $(\mathrm{Fe})$ (Table 2). These essential micronutrients might thereby contribute to both enhanced enzymatic activities and an important nutrient supply playing a crucial role in the indri physiology [35]. Further, heavy metals found in the soil, such as cobalt $(\mathrm{Co})$, chromium $(\mathrm{Cr})$, copper $(\mathrm{Cu})$, nickel $(\mathrm{Ni})$ and zinc $(\mathrm{Zn})$, were suitably below the threshold value for either ecological and health risks (Table 2) [36].

\section{Mycobiome of the Geophagic Soil and Indri}

After bioinformatics analysis, we obtained 437,872 reads clustered in 1110 OTUs (97\% identity). Rarefaction curves showed that almost all the soil and indris faecal samples nearly reached plateau (Fig. S1). We found that $74(8.9 \%)$ of the OTUs were shared between soil and indris' faeces samples 
(Fig. 2). To the best of our knowledge, only another work has investigated the possible overlap between microbial species in the gut and soil [37]. The authors analysed more than 3000 samples, finding a low number of microbial classes shared between soil and gut. In addition, we re-analysed the OTU table of Tasnim et al. [37], and we found a considerably lower percentage $(\sim 2 \%)$ of shared OTUs (i.e. soil and gut) than in our dataset.

Although with differences in relative abundance, some genera were found both in soil and indris' faeces, including Fusarium, Aspergillus, Penicillium, Apiotrichum, Ganoderma, Mortierella, Metarhizium, Tolypocladium and Chaetosphaeria (Fig. 3). Several members affiliated to the genera Fusarium, Aspergillus and Penicillium have been commonly found in primates, especially with a vegetarian diet, as well as in forest soil and leaves of herbaceous and woody plants [10, 38, 39]. In some species of Aspergillus and Penicillium is reported the presence of catalytic enzymes such as pectin methyl esterase and polygalacturonase involved in plant polysaccharide degradation [39-41]. Besides, xylanase genes linked with the degradation of xylan, xylose and/or carboxymethyl cellulose have been detected in some Fusarium species [39, 42]. Apiotrichum Mortierella and Ganoderma are soilassociated genera involved in the decomposing of plant material, and some members may be associated with mammals [43-48]. Further, Chaetosphaeria is a cosmopolitan genus mainly found in the soil, rhizosphere or plant material [43, 49], and Metarhizium and Tolypocladium are entomopathogenic fungal taxa associated with soil-borne insects $[50,51]$.
On the contrary, Candida and Cryptococcus that are frequently detected in human and non-human primates' gastrointestinal tracts were only present in faecal samples [10, 44, 52] (Fig. 3). A few species affiliated to Cryptococcus (i.e. C. neoformans) can cause Cryptococcosis, an animalassociated infectious disease with a worldwide distribution [53]. Further, these species can grow and proliferate in the decomposing wood of tree holes and the soils covered by plant debris [53-55]. Consequently, the pathogen can be spread among individuals via an environmental or zoophilic way $[53,55]$. Although we are aware of the technical limitation (i.e. short reads), the OTU 2157 (with the highest frequency among Cryptococcus OTUs) resulted in being the closest relative with $C$. neoformans (Fig. S2). The detection of this taxon could be seen as a health problem for potential overlap with humans, specifically for the rural communities present in the area.

Furthermore, fungal species only present in indris' faeces were Nigrospora and Meyerozyma, which have been frequently found in association with primates, leaves and soil [47, 56] (Fig. 3).

The high percentage of 'plant-associated' fungi in the indris' mycobiome is not surprising considering the linkages between the folivorous diet and the consequent accumulation of leaf-associated microbes in their gut (Fig. 4). For instance, these environmental fungi may survive, influence and, in some cases, colonise the gut [52]. Yet, the high percentage of 'undefined saprotrophs' fungal species may assist the breakdown of indigestible leaf cellulose and the redistribution of the nutrients [39, 57] (Fig. 4). In soil, saprophytic fungi are well known for the production of
Fig. 2 Venn diagram showing the number and percentage of shared fungal OTUs between geophagic soils and indri. OTUs were defined by $97 \%$ sequence similarity

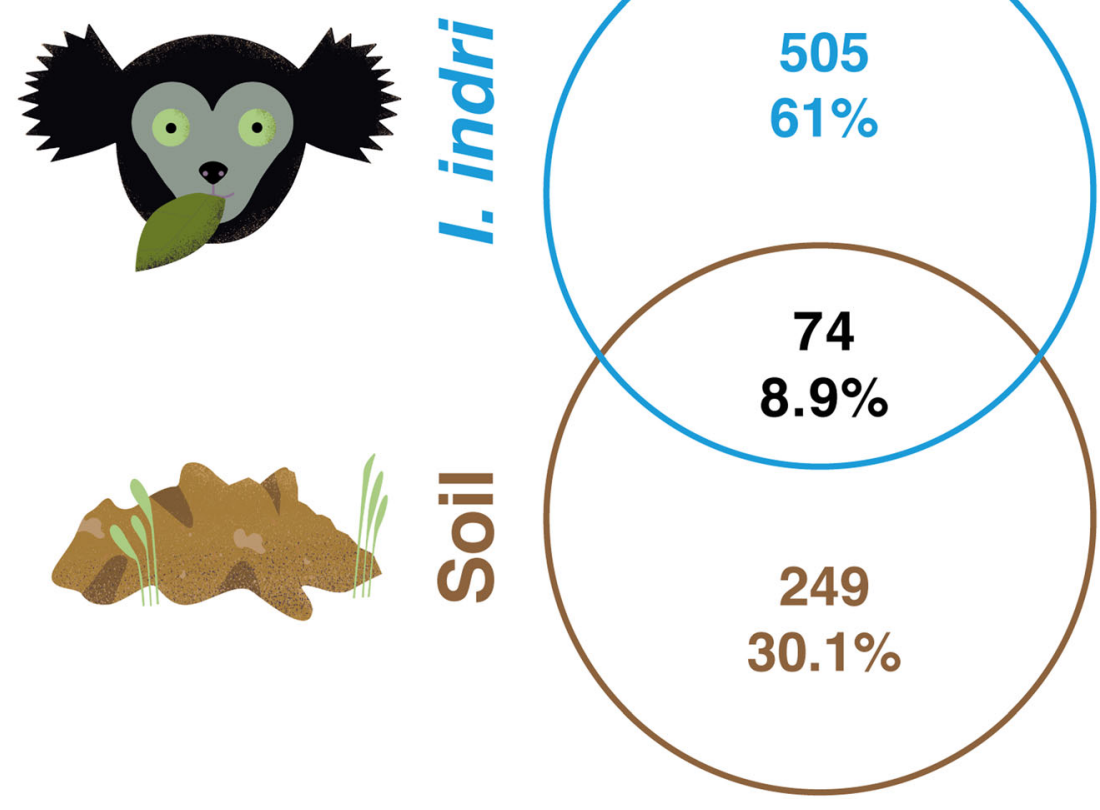




\section{Genera}

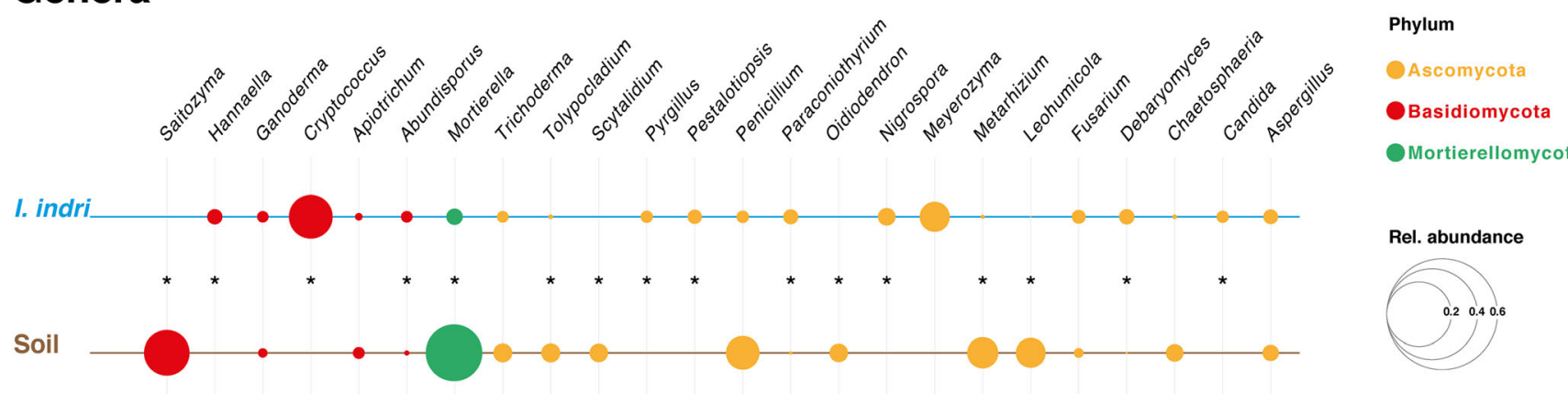

Fig. 3 Bubble plot representing the relative abundance of the most abundant Genera. The asterisk $(*)$ indicates the significative difference between soil and indri samples ( $p$ value $<0.05$ and LDA score $>2.0$ )

several secondary metabolites that play a crucial role in the initial destruction of complex organic compounds [58, 59]. Nevertheless, saprotrophic fungi could have a beneficial role in the production of enzymes necessary for the neutralisation of toxic compounds derived from the diet [60]. Although some environmental fungal species can be passengers or transient inhabitants of the indris' gut, they most likely affect the gut microbiome directly or indirectly (i.e. interaction with other microbes) [8, 61]. During geophagy, indris assumes soil microorganisms, which probably can colonise the intestine, at least in part and transiently. Thus, they effectively could fulfil a specific temporary or stable physiological role (e.g. plant polysaccharides, detoxification and production of bioactive or antimicrobial compounds) $[39,57]$. Therefore, we cannot exclude that the continuous intake of soil microorganisms through geophagy could constitute for indris a sort of 'treatment' that they seek, relevant for their health.

Fig. 4 Bar plots representing the relative abundance of predicted fungal functions/guilds. The asterisks $(*)$, indicate the significative difference between soil and indri samples $(p$ value $<$ 0.05 and LDA score $>2.0)$ LDA score and $p$ value of the most abundant genera are shown in Supplemental information (Tab. $\mathrm{S} 1$ and S2)

\section{Conclusion}

Non-human primates are of particular interest for deepening our knowledge about bacterial microbiome research, but mycobiota of wild populations have been poorly explored. Recent findings have demonstrated the link between diet, habitat integrity and bacterial and fungal diversity in the host gut, rethinking the role of gut microbiota research as a tool for conservation $[12,62,63]$. As the microbial diversity may directly impact host health [64], the fungal diversity and the characteristics of the geophagic soil could play a crucial role in the indri's health. Thus, the soil may be considered a source of some fungal species and essential nutrients [8]. With this regard, protecting the lemur habitat integrity may be reflected in protecting the integrity of gut microbial diversity, especially in specialist primates, like the leaf-eating indris. Our findings expand the current knowledge of the gut fungal diversity and geophagy in wild non-human primates that could be a baseline

\section{Guild}

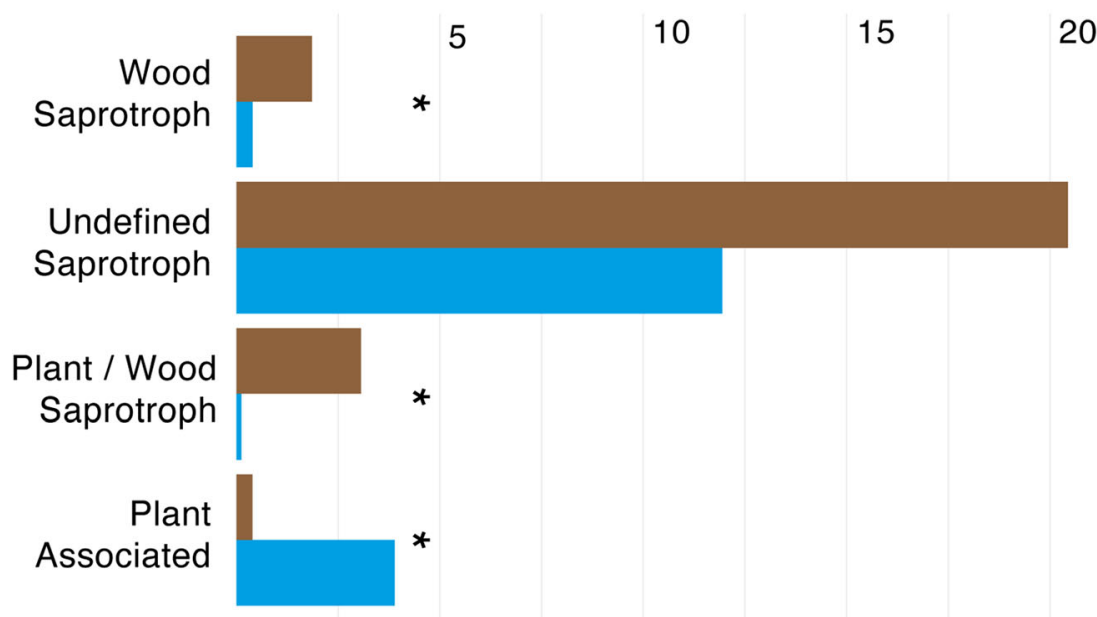


for further studies regarding the lemurs, including indris, conservation.

Supplementary Information The online version contains supplementary material available at https://doi.org/10.1007/s00248-020-01677-5.

Acknowledgements We are grateful to the Botanist, Rakotozafy M. Andriatsarafara for having contributed to the qualitative study of the soil, Matteo Moretti, for the graphics design and Manuela Dasser of Marameolab for the graphical illustrations. We thank Chiara De Gregorio and the research guides in Maromizaha (Boto Zafison, Ranaivomanana Jean and Kotoarisoa Gilbert), for collecting the faecal and soil samples and for helping us with the filming.

Funding Open Access funding provided by Libera Università di Bolzano.

\section{Compliance with Ethical Standards}

Conflict of Interest The authors declare that they have no conflict of interest.

Ethics Approval The non-invasive methods used for faecal collections of wild indris adhere to the International Primatological Society (IPS) 'Principles for the Ethical Treatment of Non-Human Primates'. Field data collection protocols were reviewed and approved by Madagascar's Ministère de 1'Environnement, de l'Ecologie et des Forêts (Permit 2018: N 91/18/MEEF/SG/DGF/DSAP/SCB.Re). Field data collection protocols were also approved by GERP (Groupe d'Étude et de Recherche sur les Primates de Madagascar), the association governing research in the Maromizaha New Protected Area.

Open Access This article is licensed under a Creative Commons Attribution 4.0 International License, which permits use, sharing, adaptation, distribution and reproduction in any medium or format, as long as you give appropriate credit to the original author(s) and the source, provide a link to the Creative Commons licence, and indicate if changes were made. The images or other third party material in this article are included in the article's Creative Commons licence, unless indicated otherwise in a credit line to the material. If material is not included in the article's Creative Commons licence and your intended use is not permitted by statutory regulation or exceeds the permitted use, you will need to obtain permission directly from the copyright holder. To view a copy of this licence, visit http://creativecommons.org/licenses/by/4.0/.

\section{References}

1. Young SL, Sherman PW, Pelto GH (2016) Why on eartH ?: evaluating hypotheses about the physiological functions of human geophagy author (s): Sera L. Young, Paul W. Sherman, Julius B . Lucks and Gretel H. Pelto Source : Quarterly Rev Biol 86(2):97-120

2. Pebsworth PA, Huffman MA, Lambert JE, Young SL (2019) Geophagy among nonhuman primates: a systematic review of current knowledge and suggestions for future directions. Am J Phys Anthropol 168:164-194. https://doi.org/10.1002/ajpa.23724

3. Semel BP, Baden AL, Salisbury RL, McGee EM, Wright PC, Arrigo-Nelson SJ (2019) Assessing the function of geophagy in a Malagasy rain forest lemur. Biotropica 51:769-780. https://doi.org/ 10.1111/btp.12699
4. Andriaholinirina N, Baden A, Blanco M, Chikhi L, Cooke A, Davies N, Dolch R, Donati G, Ganzhorn J, Golden C, Groeneveld LF, Hapke A, Irwin M, Johnson S, Kappeler P, King T, Lewis R, Louis EE, Markolf M, Mass V, Mittermeier RA, Nichols R, Patel E, Rabarivola CJ, Raharivololona B, Rajaobelina S, Rakotoarisoa G, Rakotomanga B, Rakotonanahary J, Rakotondrainibe H, Rakotondratsimba G, Rakotondratsimba M, Rakotonirina L, Ralainasolo FB, Ralison J, Ramahaleo T, Ranaivoarisoa JF, Randrianahaleo SI, Randrianambinina B, Randrianarimanana L, Randrianasolo H, Randriatahina G, Rasamimananana H, Rasolofoharivelo T, Rasoloharijaona S, Ratelolahy F, Ratsimbazafy J, Ratsimbazafy N, Razafindraibe H, Razafindramanana J, Rowe N, Salmona J, Seiler M, Volampeno S, Wright P, Youssouf J, Zaonarivelo J, Zaramody A (2020) Indri indri. The IUCN Red List of Threatened Species. The IUCN Red List of Threatened Species. Version 2020-3. https://www. iucnredlist.org

5. Britt A, Randriamandratonirina NJ, Glasscock KD, Iambana BR (2002) Diet and feeding behaviour of Indri indri in a low-altitude rain forest. Folia Primatol 73:225-239. https://doi.org/10.1159/ 000067455

6. Greene LK, Williams CV, Junge RE, Mahefarisoa KL, Rajaonarivelo T, Rakotondrainibe H, O'Connell TM, Drea CM (2020) A role for gut microbiota in host niche differentiation. ISME J 14:1675-1687. https://doi.org/10.1038/s41396020-0640-4

7. Amato KR (2016) Incorporating the gut microbiota into models of human and non-human primate ecology and evolution. Am J Phys Anthropol 159:S196-S215. https://doi.org/10.1002/ajpa.22908

8. Blum WEH, Zechmeister-Boltenstern S, Keiblinger KM (2019) Does soil contribute to the human gut microbiome? Microorganisms 7:287. https://doi.org/10.3390/ microorganisms 7090287

9. De Angelis M, Ferrocino I, Calabrese FM et al (2020) Diet influences the functions of the human intestinal microbiome. Sci Rep 10:1-15. https://doi.org/10.1038/s41598-020-61192-y

10. Hallen-Adams HE, Suhr MJ (2017) Fungi in the healthy human gastrointestinal tract. Virulence 8:352-358. https://doi.org/10. 1080/21505594.2016.1247140

11. Mackie RI (2002) Mutualistic fermentative digestion in the gastrointestinal tract: diversity and evolution. Integr Comp Biol 42:319326. https://doi.org/10.1093/icb/42.2.319

12. Barelli C, Albanese D, Stumpf RM et al (2020) The gut microbiota communities of wild arboreal and ground-feeding tropical primates are affected differently by habitat disturbance. mSystems 5:1-18. https://doi.org/10.1128/msystems.00061-20

13. Chin VK, Yong VC, Chong PP, Amin Nordin S, Basir R, Abdullah M (2020) Mycobiome in the gut: a multiperspective Review. Mediat Inflamm 2020:1-16. https://doi.org/10.1155/2020/9560684

14. Nash AK, Auchtung TA, Wong MC, Smith DP, Gesell JR, Ross MC, Stewart CJ, Metcalf GA, Muzny DM, Gibbs RA, Ajami NJ, Petrosino JF (2017) The gut mycobiome of the Human Microbiome Project healthy cohort. Microbiome 5:153. https://doi.org/10.1186/ s40168-017-0373-4

15. Bonadonna G, Torti V, De Gregorio C et al (2019) Evidence of genetic monogamy in the lemur Indri (Indri indri). Am J Primatol 81:e22993. https://doi.org/10.1002/ajp.22993

16. Torti V, Gamba M, Rabemananjara ZH, Giacoma C (2013) The songs of the indris (Mammalia: Primates: Indridae): contextual variation in the long-distance calls of a lemur. Ital J Zool 80:596-607. https://doi.org/10.1080/11250003.2013.845261

17. Sparks L, Page AL, Helmke PA, Loeppert RH, Soltanpour PN, Tabatabai MA, Johnson CT, Sumner ME (1996) Methods of Soil Analysis: Part 3-Chemical Methods. Soil Science Society of America, Washington, DC 
18. Tang J, Iliev ID, Brown J, Underhill DM, Funari VA (2015) Mycobiome: approaches to analysis of intestinal fungi. $\mathrm{J}$ Immunol Methods 421:112-121. https://doi.org/10.1016/j.jim. 2015.04.004

19. White TJ, Bruns T, Lee S, Taylor JW (1990) Amplification and direct sequencing of fungal Ribosomal RNA genes for phylogenetics. Academic P, New York

20. Andrews S (2010) FastQC: a quality control tool for high throughput sequence data. (http://www.bioinformatics.babraham.ac.uk/ projects/fastqc)

21. Bolyen E, Rideout JR, Dillon MR, Bokulich NA, Abnet CC, alGhalith GA, Alexander H, Alm EJ, Arumugam M, Asnicar F, Bai Y, Bisanz JE, Bittinger K, Brejnrod A, Brislawn CJ, Brown CT, Callahan BJ, Caraballo-Rodríguez AM, Chase J, Cope EK, da Silva R, Diener C, Dorrestein PC, Douglas GM, Durall DM, Duvallet C, Edwardson CF, Ernst M, Estaki M, Fouquier J, Gauglitz JM, Gibbons SM, Gibson DL, Gonzalez A, Gorlick K, Guo J, Hillmann B, Holmes S, Holste H, Huttenhower C, Huttley GA, Janssen S, Jarmusch AK, Jiang L, Kaehler BD, Kang KB, Keefe CR, Keim P, Kelley ST, Knights D, Koester I, Kosciolek T, Kreps J, Langille MGI, Lee J, Ley R, Liu YX, Loftfield E, Lozupone C, Maher M, Marotz C, Martin BD, McDonald D, McIver LJ, Melnik AV, Metcalf JL, Morgan SC, Morton JT, Naimey AT, NavasMolina JA, Nothias LF, Orchanian SB, Pearson T, Peoples SL, Petras D, Preuss ML, Pruesse E, Rasmussen LB, Rivers A, Robeson II MS, Rosenthal P, Segata N, Shaffer M, Shiffer A, Sinha R, Song SJ, Spear JR, Swafford AD, Thompson LR, Torres PJ, Trinh P, Tripathi A, Turnbaugh PJ, Ul-Hasan S, van der Hooft JJJ, Vargas F, Vázquez-Baeza Y, Vogtmann E, von Hippel M, Walters W, Wan Y, Wang M, Warren J, Weber KC, Williamson CHD, Willis AD, Xu ZZ, Zaneveld JR, Zhang Y, Zhu Q, Knight R, Caporaso JG (2019) Reproducible, interactive, scalable and extensible microbiome data science using QIIME 2. Nat Biotechnol 37: 852-857. https://doi.org/10.1038/s41587-019-0209-9

22. Callahan BJ, McMurdie PJ, Rosen MJ et al (2016) DADA2: highresolution sample inference from Illumina amplicon data. Nat Methods 13:581-583. https://doi.org/10.1038/nmeth.3869

23. Rognes T, Flouri T, Nichols B, Quince C, Mahé F (2016) VSEARCH: a versatile open source tool for metagenomics. PeerJ 4:e2584. https://doi.org/10.7717/peerj.2584

24. Nilsson RH, Larsson KH, Taylor AFS, Bengtsson-Palme J, Jeppesen TS, Schigel D, Kennedy P, Picard K, Glöckner FO, Tedersoo L, Saar I, Kõljalg U, Abarenkov K (2019) The UNITE database for molecular identification of fungi: handling dark taxa and parallel taxonomic classifications. Nucleic Acids Res 47: D259-D264. https://doi.org/10.1093/nar/gky1022

25. Nguyen NH, Song Z, Bates ST, Branco S, Tedersoo L, Menke J, Schilling JS, Kennedy PG (2016) FUNGuild: an open annotation tool for parsing fungal community datasets by ecological guild. Fungal Ecol 20:241-248. https://doi.org/10.1016/j.funeco.2015. 06.006

26. Larkin MA, Blackshields G, Brown NP, Chenna R, McGettigan PA, McWilliam H, Valentin F, Wallace IM, Wilm A, Lopez R, Thompson JD, Gibson TJ, Higgins DG (2007) Clustal W and Clustal X version 2.0. Bioinformatics 23:2947-2948. https://doi. org/10.1093/bioinformatics/btm404

27. Kumar S, Stecher G, Li M, Knyaz C, Tamura K (2018) MEGA X: molecular evolutionary genetics analysis across computing platforms. Mol Biol Evol 35:1547-1549. https://doi.org/10.1093/ molbev/msy096

28. Wickham H (2016) ggplot2: elegant graphics for data analysis. Springer-V, New York

29. Oksanen AJ, Blanchet FG, Friendly M, et al (2018) Package ' vegan'
30. R Core Team (2018) R: A language and environment for statistical computing. R Foundation for Statistical Computing, Vienna, Austria. https://www.R-project.org/

31. Segata N, Izard J, Waldron L, Gevers D, Miropolsky L, Garrett WS, Huttenhower C (2011) Metagenomic biomarker discovery and explanation. Genome Biol 12:R60. https://doi.org/10.1186/gb-201112-6-r60

32. Vågen TG, Andrianorofanomezana MAA, Andrianorofanomezana S (2006) Deforestation and cultivation effects on characteristics of oxisols in the highlands of Madagascar. Geoderma 131:190-200. https://doi.org/10.1016/j.geoderma.2005.03.026

33. De Souza LL, Ferrari SF, Da Costa ML, Kern DC (2002) Geophagy as a correlate of folivory in red-handed howler monkeys (Alouatta belzebul) from Eastern Brazilian Amazonia. J Chem Ecol 28:16131621. https://doi.org/10.1023/A:1019928529879

34. Kambunga SN, Candeias C, Hasheela I, Mouri H (2019) Review of the nature of some geophagic materials and their potential health effects on pregnant women: some examples from Africa. Environ Geochem Health 41:2949-2975. https://doi.org/10.1007/s10653019-00288-5

35. Krishnamani R, Mahaney WC (2000) Geophagy among primates: adaptive significance and ecological consequences. Anim Behav 59:899-915. https://doi.org/10.1006/anbe.1999.1376

36. Tóth G, Hermann T, Da Silva MR, Montanarella L (2016) Heavy metals in agricultural soils of the European Union with implications for food safety. Environ Int 88:299-309. https://doi.org/10.1016/j. envint.2015.12.017

37. Tasnim N, Abulizi N, Pither J, Hart MM, Gibson DL (2017) Linking the gut microbial ecosystem with the environment: does gut health depend on where we live? Front Microbiol 8:1-8. https:// doi.org/10.3389/fmicb.2017.01935

38. Huseyin CE, O'Toole PW, Cotter PD, Scanlan PD (2017) Forgotten fungi-the gut mycobiome in human health and disease. FEMS Microbiol Rev 41:479-511. https://doi.org/10.1093/femsre/ fuw047

39. Sun B, Huffman MA, Li J-H (2020) The gut microbiome of tibetan macaques: composition, influencing factors and function in feeding ecology. In: Li J-H, Sun L, Kappeler PM (eds) The behavioral ecology of the tibetan macaque. Springer International Publishing, Cham, pp 207-222

40. Tu T, Bai Y, Luo H, Ma R, Wang Y, Shi P, Yang P, Meng K, Yao B (2014) A novel bifunctional pectinase from Penicillium oxalicum SX6 with separate pectin methylesterase and polygalacturonase catalytic domains. Appl Microbiol Biotechnol 98:5019-5028. https://doi.org/10.1007/s00253-014-5533-X

41. Tu T, Meng K, Luo H, Turunen O, Zhang L, Cheng Y, Su X, Ma R, Shi P, Wang Y, Yang P, Yao B (2015) New insights into the role of T3 loop in determining catalytic efficiency of GH28 endopolygalacturonases. PLoS One 10:1-16. https://doi.org/10.1371/ journal.pone. 0135413

42. Hatsch D, Phalip V, Petkovski E, Jeltsch JM (2006) Fusarium graminearum on plant cell wall: no fewer than 30 xylanase genes transcribed. Biochem Biophys Res Commun 345:959-966. https:// doi.org/10.1016/j.bbrc.2006.04.171

43. Purahong W, Pietsch KA, Bruelheide H, Wirth C, Buscot F, Wubet $\mathrm{T}$ (2019) Potential links between wood-inhabiting and soil fungal communities: evidence from high-throughput sequencing. Microbiologyopen 8:1-14. https://doi.org/10.1002/mbo3.856

44. Hamad I, Keita MB, Peeters M, Delaporte E, Raoult D, Bittar F (2014) Pathogenic eukaryotes in gut microbiota of western lowland gorillas as revealed by molecular survey. Sci Rep 4:1-9. https://doi. org/10.1038/srep06417

45. Chang CJ, Lin CS, Lu CC, Martel J, Ko YF, Ojcius DM, Tseng SF, Wu TR, Chen YYM, Young JD, Lai HC (2015) Ganoderma lucidum reduces obesity in mice by modulating the composition 
of the gut microbiota. Nat Commun 6:7489. https://doi.org/10. 1038/ncomms 8489

46. Jayachandran M, Xiao J, Xu B (2017) A critical review on health promoting benefits of edible mushrooms through gut microbiota. Int J Mol Sci 18:18. https://doi.org/10.3390/ijms18091934

47. Buzzini P, Lachance MA, Yurkov A (2017) Yeasts in natural ecosystems: diversity. Yeasts Nat Ecosyst Divers 1-499. https://doi. org/10.1007/978-3-319-62683-3

48. Hurst CJ (2019) Dirt and disease: the ecology of soil fungi and plant fungi that are infectious for vertebrates. In: Hurst CJ (ed) Understanding Terrestrial Microbial Communities. Springer International Publishing, Cham, pp 289-405

49. Fernández FA, Miller AN, Huhndorf SM et al (2006) Systematics of the genus Chaetosphaeria and its allied genera: morphological and phylogenetic diversity in north temperate and neotropical taxa. Mycologia 98:121-130. https://doi.org/ 10.3852/mycologia.98.1.121

50. St. Leger RJ (2008) Studies on adaptations of Metarhizium anisopliae to life in the soil. J Invertebr Pathol 98:271-276. https://doi.org/10.1016/j.jip.2008.01.007

51. Sung GH, Hywel-Jones NL, Sung JM, Luangsa-ard JJ, Shrestha B, Spatafora JW (2007) Phylogenetic classification of Cordyceps and the clavicipitaceous fungi. Stud Mycol 57:5-59. https://doi.org/10. 3114/sim.2007.57.01

52. Lai GC, Tan TG, Pavelka N (2018) The mammalian mycobiome: a complex system in a dynamic relationship with the host. Wiley Interdiscip Rev Syst Biol Med 11:1-22. https://doi.org/10.1002/ wsbm. 1438

53. Seyedmousavi S, Guillot JG, de Hoog GS, Verweij PE (2018) Emerging and Epizootic Fungal Infections. In: Seyedmousavi S, Guillot JG, de Hoog GS, Verweij PE (eds) Springer publishing. https://www.springer.com/us/book/ 9783319720913

54. Cogliati M, Patrizia P, Vincenzo C, Esposto MC, Prigitano A, Romanò L, Puccianti E (2020) Cryptococcus neoformans species complex isolates living in a tree micro-ecosystem. Fungal Ecol 44: 100889. https://doi.org/10.1016/j.funeco.2019.100889

55. Springer DJ, Mohan R, Heitman J (2017) Plants promote mating and dispersal of the human pathogenic fungus Cryptococcus. PLoS One 12:1-21. https://doi.org/10.1371/journal.pone.0171695
56. Inácio J, Daniel H-M (2017) Commensalism: the case of the human zymobiome. In: Buzzini P, Lachance M-A, Yurkov A (eds) Yeasts in Natural Ecosystems: Ecology. Springer International Publishing, Cham, pp 211-228

57. Jiang H, Chen W, Su L, Huang M, Lin L, Su Q, Li G, Ahmad HI, Li L, Zhang X, Li H, Chen J (2020) Impact of host intraspecies genetic variation, diet, and age on bacterial and fungal intestinal microbiota in tigers. Microbiologyopen 9:1-22. https://doi.org/10.1002/mbo3.1050

58. Bani A, Borruso L, Matthews Nicholass KJ, Bardelli T, Polo A, Pioli S, Gómez-Brandón M, Insam H, Dumbrell AJ, Brusetti L (2019) Site-specific microbial decomposer communities do not imply faster decomposition: results from a litter transplantation experiment. Microorganisms 7:1-16. https://doi.org/10.3390/ microorganisms 7090349

59. Baldrian P, Valášková V (2008) Degradation of cellulose by basidiomycetous fungi. FEMS Microbiol Rev 32:501-521. https://doi. org/10.1111/j.1574-6976.2008.00106.x

60. Iliev ID, Leonardi I (2017) Fungal dysbiosis: immunity and interactions at mucosal barriers. Nat Rev Immunol 17:635-646. https:// doi.org/10.1038/nri.2017.55

61. Kapitan M, Niemiec MJ, Steimle A et al (2019) Fungi as part of the microbiota and interactions with intestinal bacteria. In: Rodrigues ML (ed) Fungal Physiology and Immunopathogenesis. Springer International Publishing, Cham, pp 265-301

62. Springer A, Fichtel C, Al-Ghalith GA et al (2017) Patterns of seasonality and group membership characterize the gut microbiota in a longitudinal study of wild Verreaux's sifakas (Propithecus verreauxi). Ecol Evol 7:5732-5745. https://doi. org/10.1002/ece3.3148

63. Fogel AT (2015) The gut microbiome of wild Lemurs: a comparison of sympatric Lemur catta and Propithecus verreauxi. Folia Primatol 86:85-95. https://doi.org/10.1159/000369971

64. Marchesi JR, Adams DH, Fava F, Hermes GDA, Hirschfield GM, Hold G, Quraishi MN, Kinross J, Smidt H, Tuohy KM, Thomas LV, Zoetendal EG, Hart A (2016) The gut microbiota and host health: a new clinical frontier. Gut 65:330-339. https://doi.org/10. 1136/gutjnl-2015-309990 